THE NATURE OF CAPITAL AND INCOME 
The 


\title{
THE NATURE OF CAPITAL AND INCOME
}

\author{
BY \\ IRVING FISHER, Рн.D. \\ PROFESSOR OF POLITICAL ECONOMY, YALE UNTERSITY
}

Nerio Gork

THE MACMILLAN COMPANY

LONDON : MACMILLAN \& CO., LTD.

1906

All rights reserved 


\section{Copretert, 1906,}

\section{BY THE MACMLLLAN COMPANY.}

Set up and electrotyped. Published September, 1906.

Norwood 3ress

J. 8. Cushing \& Co. - Berwick \& Smith Co. Norwood, Mass., U.S.A. 
TO

WILLIAM GRAHAM SUMNER

WHO FIRST INSPIRED ME

WITH

A LOVE FOR

ECONOMIC SCIENCE 
